\title{
Microangiopathic Hemolytic Anemia Following Three Different Species of Hump-Nosed Pit Viper (Genus: Hypnale) Envenoming in Sri Lanka
}

\author{
Rathnayaka Mudiyanselage M.K. Namal Rathnayaka, MBBS, MA, MSc in Medical Tox., Dip. in Tox., Dip. in \\ OH\&S.; Anusha Nishanthi Ranathunga, MBBS; Senanayake A.M. Kularatne, MBBS, MD, MRCP (UK), FRCP \\ (Lond); Jayanthe Rajapakse, BVSc, PhD; Shirani Ranasinghe, BVSc, M.Phil, PhD; Radha Jayathunga, MBBS, \\ Dip.in Pathology, MD (Haematology) \\ From the Department of Veterinary Pathobiology, Faculty of Veterinary Medicine and Animal Science, University of Peradeniya, Peradeniya, \\ Sri Lanka (Drs Rathnayaka and Rajapakse); the Faculty of Medicine, University of Peradeniya, Peradeniya, Sri Lanka (Drs Kularatne and \\ Ranasinghe); the Intensive Care Unit/Anaesthesia, Provincial General Hospital, Ratnapura, Sri Lanka (Dr Rathnayaka); the Medical Unit, \\ Provincial General Hospital, Ratnapura, Sri Lanka (Dr Ranathunga); and the Haematology Unit, Provincial General Hospital, Ratnapura, \\ Sri Lanka (Dr Jayathunga).
}

\begin{abstract}
There are 3 species of hump-nosed pit vipers in Sri Lanka: Hypnale hypnale, Hypnale zara, and Hypnale nepa. The latter 2 are endemic to the country. Microangiopathic hemolytic anemia (MAHA) is a known complication of hump-nosed pit viper bites. It was previously documented as a complication of general viper bites and not species specific. We report a series of 3 patients who developed MAHA after being bitten by each species of hump-nosed pit viper. The first patient was bitten by $H$ hypnale and developed a severe form of MAHA associated with acute kidney injury and thrombocytopenia falling into the category of thrombotic microangiopathy. The other 2 developed MAHA that resolved without any complications.
\end{abstract}

Keywords: snakebites, Hypnale hypnale, Hypnale zara, Hypnale nepa

\section{Introduction}

The genus Hypnale comprises 3 species of hump-nosed pit vipers, Hypnale hypnale, Hypnale zara, and Hypnale nepa, which inhabit Sri Lanka. ${ }^{1}$ Of them, H hypnale is found both in Sri Lanka and Western Ghats of India, whereas $H$ zara and $H$ nepa are endemic to Sri Lanka. Therefore, these 2 endemic species generally are recognized as Sri Lankan hump-nosed pit vipers.

Hump-nosed pit vipers are the most common cause of all snakebites in Sri Lanka, ${ }^{2,3}$ and account for 22 to $77 \%$ of all snakebites. ${ }^{4,5}$ Of these 3 species, $H$ hypnale is widely distributed and recorded the most frequent bites, followed by $H$ zara and $H$ nepa, respectively. ${ }^{6,7} H$ zara is found in lowland rain forests. It is found only in primary and secondary forests and is essentially nocturnal. ${ }^{1}$ Therefore, its bites are less common compared with $H$ hypnale.

Corresponding author: Rathnayaka Mudiyanselage M.K. Namal Rathnayaka, MBBS, MA, MSc in Medical Tox., Dip. in Tox., Dip. in OH\&S, No.181, Flower Road, New Town Housing Scheme 01, New Town, Ratnapura, Sri Lanka; e-mail: namalrath@yahoo.com.

Submitted for publication July 2017.

Accepted for publication November 2017.
$H$ nepa inhabits the central hills of the island, whereas $H$ hypnale is distributed throughout areas below $600 \mathrm{~m}$.

The clinical picture and complications after $H$ zara and $H$ nepa bites are not well documented in the literature due to inability to identify the species correctly using the standard key and also due to the relative infrequency of their bites. We have to appreciate the fact that to the naked and untrained eye, all 3 species look alike. General Hospital, Ratnapura, being situated in the wet zone of the island, has the rare opportunity to receive cases of hump-nosed pit viper bites from all 3 species. In this case report, we describe 3 cases of proven genus Hypnale bites; we describe the circumstances in which the victim was bitten, the clinical picture, and the development of microangiopathic hemolysis (MAHA), a rare complication of snakebite envenomation. Thus, our report contains the first documentation of MAHA after envenoming by $H$ zara and $H$ nepa.

\section{Case report}

\section{CASE 1}

A 48-year-old, previously healthy married gem miner was bitten by a hump-nosed pit viper at about 2100 hours on a 


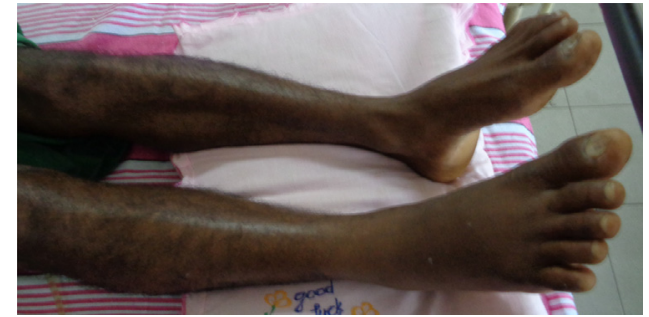

Figure 1. Site of bite in case 1 patient-right foot.

day in July while walking on a footpath in his home garden. The bite occurred on his right foot, and he was admitted to the hospital at 2200 hours. The offending snake was killed and brought to the hospital along with the patient, and it was identified by the attending medical officer. The patient lives in 'Udaniriella,' a remote village in the Ratnapura district, and he had not taken native treatment before the hospital admission, nor applied any first aid.

On admission, he was experiencing nausea, vomiting, abdominal pain, and severe local pain at the site of the bite. On examination, there was a fang puncture and moderate local swelling of the bitten foot (Figure 1). His blood pressure was $140 / 80 \mathrm{~mm} \mathrm{Hg}$, and his pulse rate was 108 beats $\cdot \mathrm{min}^{-1}$. His respiratory rate was 15 breaths $\cdot \mathrm{min}^{-1}$, and examination of respiratory system, nervous system, and abdomen revealed no abnormality. His 20-min whole blood clotting test on admission and on subsequent readings at 6-h intervals remained normal for $48 \mathrm{~h}$. Other investigation findings are mentioned in Table 1. A blood picture done 2 days after the snakebite showed normochromic-normocytic red cells and fragmented red blood cells (schistocytes $>8$ in $\times 100$ field) with few polychromatics and spherocytes suggestive of microangiopathic hemolytic anemia (Figure 2). From day 2 after the snakebite onward, the patient developed gradual elevation of blood urea and serum creatinine (Figure 3), but he maintained normal urine output with oral furosemide $40 \mathrm{mg}$ twice daily.

On day 5 , the patient had a high serum $\mathrm{K}^{+}$level $(6.2$ $\left.\mathrm{mmol} \cdot \mathrm{L}^{-1}\right)$, which responded to insulin/dextrose bolus.

Table 1. Laboratory findings of case 1 patient

\begin{tabular}{|c|c|c|c|c|c|c|c|c|c|c|c|}
\hline \multirow[t]{2}{*}{ Laboratory investigation } & \multicolumn{11}{|c|}{ Day } \\
\hline & 1 & 3 & 4 & 5 & 6 & 7 & 8 & 9 & 10 & 11 & 14 \\
\hline WBC $\left(\times 10^{3} \mu \mathrm{L}^{-1}\right)$ & 5.6 & 9.8 & & 7 & 8.1 & 8.9 & 7.7 & 7.3 & 7.7 & 9.6 & \\
\hline Neutrophils (\%) & 38.5 & 82.4 & & 72 & 63.7 & 75.2 & 78.5 & 61.4 & 71.4 & 77.3 & \\
\hline Lymphocytes (\%) & 52.6 & 9.9 & & 23 & 15.6 & 10.8 & 16.9 & 20.7 & 11.2 & 18.7 & \\
\hline Platelets $\left(\times 10^{3} \mathrm{~g} \cdot \mathrm{uL}^{-1}\right)$ & 221 & 62 & & 34 & 26 & 63 & 91 & 129 & 261 & 319 & \\
\hline $\mathrm{Hb}\left(\mathrm{g} \cdot \mathrm{dL}^{-1}\right)$ & 12.1 & 12.3 & & 9.6 & 8.6 & 9 & 8.8 & 6.7 & 8.8 & 8.4 & \\
\hline $\operatorname{PCV}(\%)$ & 37.1 & 37.3 & & 29.3 & 26.2 & 26.9 & 25.9 & 20.6 & 27.2 & 24.2 & \\
\hline MCV (normal 80-95.5 fL) & 84.2 & 81.9 & & 81.9 & 81.7 & 82.1 & 82.2 & 83.9 & 82.6 & 79.8 & \\
\hline $\mathrm{MCH}$ (normal 27-31 Pg) & 27.6 & 26.9 & & 26.8 & 26.8 & 27.5 & 27.8 & 27.3 & 26.7 & 27.7 & \\
\hline MCHC (normal 33-37 $\mathrm{g} \cdot \mathrm{dL}^{-1}$ ) & 32.8 & 32.9 & & 32.7 & 32.8 & 33.5 & 33.8 & 32.6 & 32.3 & 34.7 & \\
\hline RBC count (normal 4-6 $\times 10^{6} \mathrm{~g} \cdot \mathrm{uL}^{-1}$ ) & 4.4 & 4.5 & & 3.5 & 3.2 & 3.2 & 3.1 & 2.4 & 3.2 & 3 & \\
\hline MPV (normal 7.8-11 fL) & 8.6 & 7.8 & & 9.5 & 9.3 & 10.4 & 9.2 & 7.6 & 8.6 & 7.5 & \\
\hline Serum creatinine $\left(\mu \mathrm{mol} \cdot \mathrm{L}^{-1}\right)$ & 87 & 358.4 & 454 & 419 & 598 & 582.1 & 423 & 532 & 296.2 & 235 & 128 \\
\hline Blood urea $\left(\mathrm{mmol} \cdot \mathrm{L}^{-1}\right)$ & 3.4 & 12.3 & 17.7 & 19 & 25.4 & 27.2 & 24.1 & 20.8 & 16.9 & 18.7 & 10.5 \\
\hline $\mathrm{Na}^{+}\left(\mathrm{mmol} \cdot \mathrm{L}^{-1}\right)$ & 137 & 140 & 135 & 134 & 134 & 132 & 126 & 131 & 137 & 128 & \\
\hline $\mathrm{K}^{+}\left(\mathrm{mmol} \cdot \mathrm{L}^{-1}\right)$ & 3.8 & 4.5 & 4.4 & 6.2 & 4.9 & 5.4 & 4.1 & 4.3 & 4.3 & 4 & \\
\hline PT (s) & $12.7 / 12$ & & & $12.7 / 12$ & $13.2 / 12$ & $13.6 / 12$ & $16 / 12$ & $13 / 12$ & & $14 / 12$ & \\
\hline INR & 1.06 & & & 1.06 & 1.10 & 1.14 & 1.34 & 1.08 & & 1.18 & \\
\hline APTT (s) & $27.6 / 30$ & & & $27.6 / 30$ & $28 / 30$ & $27.7 / 30$ & $30 / 30$ & $30 / 30$ & & $21 / 30$ & \\
\hline SGOT (AST) $\left[\mathrm{U} \cdot \mathrm{I}^{-1}\right]$ & 26 & & 31.3 & 34 & 32.8 & 65.5 & 103 & 73 & 24 & 19 & \\
\hline SGPT (ALT) $\left[{\left.\mathrm{U} \cdot \mathrm{I}^{-1}\right]}^{-1}\right.$ & 19 & & 13.2 & 18 & 24.4 & 81.3 & 56 & 31 & 48.8 & 43 & \\
\hline Total bilirubin $\left(\mu \mathrm{mol} \cdot \mathrm{L}^{-1}\right)$ & & 49.5 & 56.7 & 55 & 41.5 & 17.7 & 10.8 & 7.9 & 6.71 & 6.7 & \\
\hline Direct bilirubin $\left(\mu \mathrm{mol} \cdot \mathrm{L}^{-1}\right)$ & & 10.5 & 16.4 & 14.1 & 12.3 & & & & & & \\
\hline $\operatorname{ALP}\left(\mathrm{U} \cdot \mathrm{I}^{-1}\right)$ & & 151.5 & 148 & & 182 & 195.7 & & & & & \\
\hline
\end{tabular}

WBC, white blood cells; $\mathrm{Hb}$, hemoglobin; $\mathrm{PCV}$, packed cell volume; $\mathrm{MCV}$, mean corpuscular volume; $\mathrm{MCH}$, mean corpuscular hemoglobin; MCHC, mean corpuscular hemoglobin concentration; RBC, red blood cell; MPV, mean platelet volume; $\mathrm{Na}^{+}$, blood sodium level; $\mathrm{K}^{+}$, potassium; PT, prothrombin time; INR, international normalized ratio; APTT, activated partial thromboplastin time; SGOT, serum glutamic-oxaloacetic transaminase; AST, aspartate aminotransferase; SGPT, serum glutamic pyruvic transaminase; ALT, alanine aminotransferase; ALP, alkaline phosphatase. 
(A)

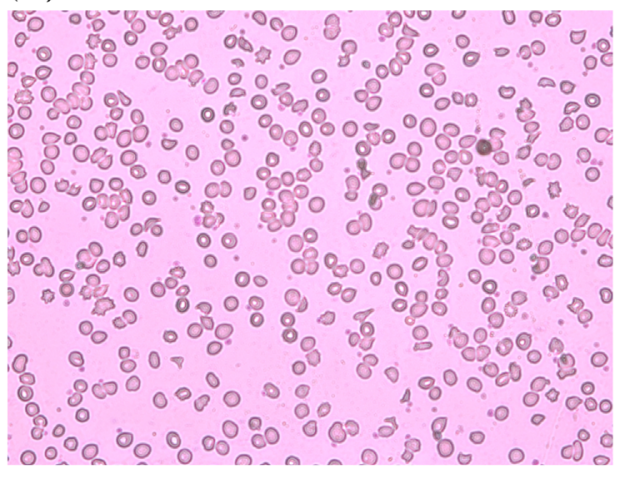

(B)

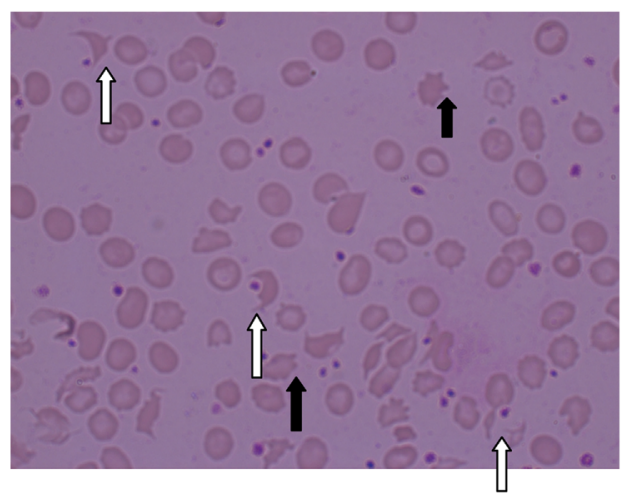

Figure 2. Peripheral blood smear on day 2 after snakebite in case 1 patient. Note that MAHA is indicated from presence of fragmented red blood cells (white arrow) $>8$ in high power field (B). Black arrow indicates acanthocytes. A, $\times 40 ; \mathrm{B}, \times 100$. MAHA, microangiopathic hemolytic anemia.

He also had elevated serum bilirubin up to day 7 after the snakebite, which was spontaneously corrected. He also experienced thrombocytopenia and moderate anemia. On day 9 , because hemoglobin was $6.7 \mathrm{~g} \cdot \mathrm{dL}^{-1}$, one pack of blood was transfused. He was discharged on day 14 when urine output, blood urea, and serum creatinine were normal (Figure 3). By using the key described by Maduwage et al, ${ }^{1}$ the species of hump-nosed pit viper was identified as $H$ hypnale (Figure 4).

\section{CASE 2}

A 70-year-old man was admitted to the medical unit at Provincial General Hospital, Ratnapura, Sri Lanka at 0830 hours in November after a hump-nosed viper bite on his left foot lateral margin at about 0700 hours in the morning. He lives in the suburb city of Kuruvita $\left(06^{\circ} 40^{\prime} \mathrm{N}, 80^{\circ} 24^{\prime}\right.$, elevation $130 \mathrm{~m}$ [430 ft]), and the bite occurred while he was walking in his home garden in the early morning. The site of the bite was not washed, but a ligature had been applied above the ankle and was present for approximately $45 \mathrm{~min}$. His preexisting comorbidities included hypertension and type 2 diabetes mellitus, which were treated with enalapril $5 \mathrm{mg}$ and

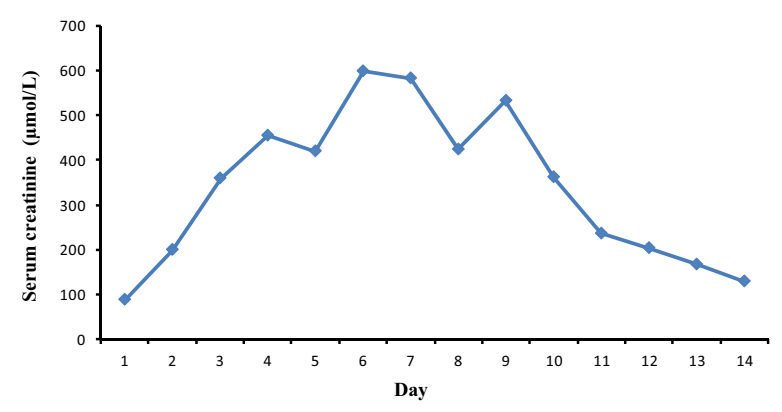

Figure 3. Changes in serum creatinine in case 1 patient. metformin $500 \mathrm{mg} 2$ times per day, respectively. The offending live snake was brought along with the patient and identified as a hump-nosed pit viper by the attending medical officer.

The patient was not given any native treatments, including local application. On admission, he had severe local pain, and urine output was normal. On examination, there was moderate swelling of the left foot, and a fang mark could be identified (Figure 5). There was no bleeding from the site of the bite and no tender lymph nodes in the groin. His blood pressure was 150/80 mm $\mathrm{Hg}$, and his pulse rate was 80 beats $\cdot \mathrm{min}^{-1}$. His respiratory rate was 15 breaths $\mathrm{min}^{-1}$, and examination of respiratory system, nervous system, and abdomen revealed no abnormality.

His 20-min whole blood clotting test on admission and subsequent readings at 6-h intervals remained normal for $24 \mathrm{~h}$. Random blood sugar was $99 \mathrm{mg} \cdot \mathrm{dL}^{-1}$; urinalysis and electrocardiogram were normal. Other laboratory findings are shown in Table 2. A blood picture done $7 \mathrm{~h}$ after the snakebite showed normochromic-normocytic red cells, few polychromatics, acanthocytes, and few fragmented red blood cells $(>5$ in $\times 100$ field) suggestive of microangiopathic hemolytic anaemia (Figure 6). He maintained normal urine output throughout the hospital stay and was discharged on day 3 after the snakebite. According to the key described by Maduwage et al, ${ }^{1}$ the species of hump-nosed pit viper was identified as $H$ zara (Figure 7).

\section{CASE 3}

A 53-year-old male engineer was bitten by a humpnosed pit viper at 0230 hours in February while he was descending from Sripada (Adam's peak) with others. The bite occurred on his left foot at an altitude of 6000 
(A)

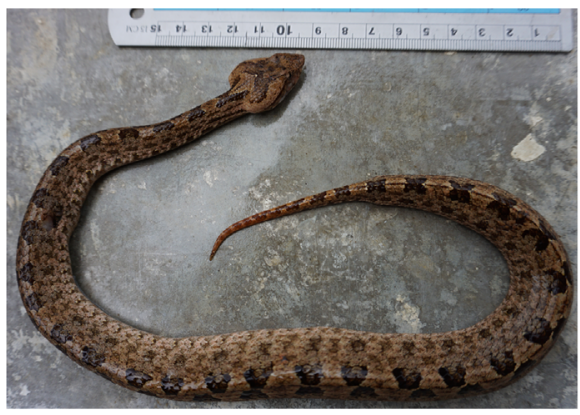

(B)

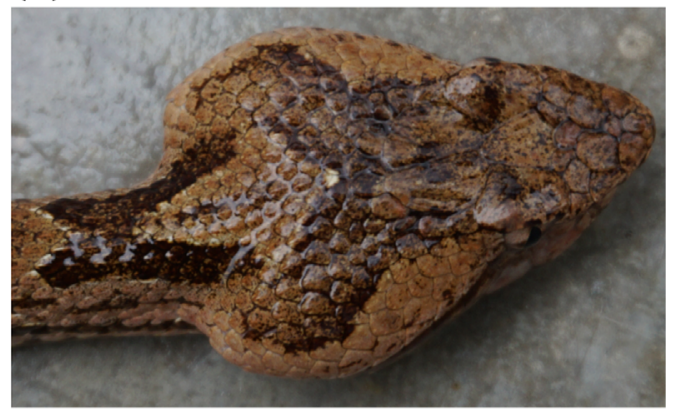

(C)

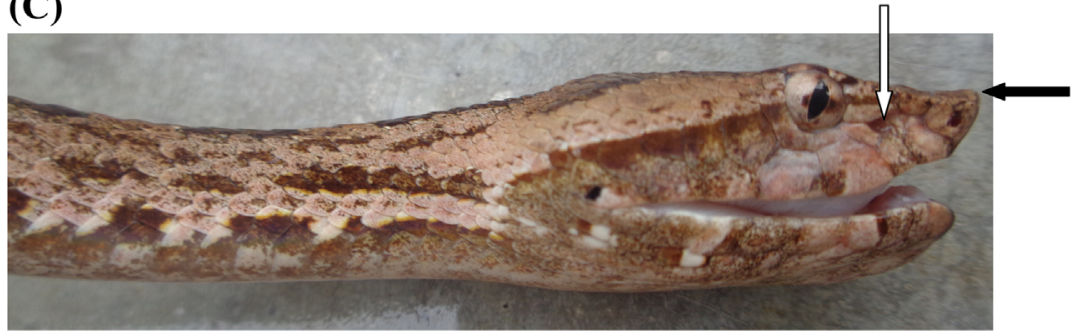

Figure 4. A, Dead offending snake (case 1)—H hypnale, a female snake $482 \mathrm{~mm}$ in total length. Note that costal scales are keeled. B, Five large head scales. C, Note that the wart-like protuberance at the tip of the snout (hump-indicated in black arrow) is not prominent (vs raised in $H$ zara). White arrow indicates that the pit organ (loreal pit), which is a characteristic feature of pit vipers, is between the eye and the snout.

m. He was receiving regular treatment for hypercholesterolemia (atrovastatin $10 \mathrm{mg}$, nocte). The snake was killed and brought to the hospital along with the patient.

The patient was free of symptoms except for mild pain at the bitten site on admission. On examination, there was mild local swelling and a fang puncture on the lateral side of the left foot. No local bleeding or lymphadenopathy was observed. Blood pressure was $120 / 70 \mathrm{~mm} \mathrm{Hg}$; pulse rate was 80 beats. $\mathrm{min}^{-1}$; and other examination findings were normal. Twenty-minute whole blood clotting test done on admission and $6 \mathrm{~h}$ later was normal. His random blood sugar was $105 \mathrm{mg} \cdot \mathrm{dL}^{-1}$; urinalysis and electrocardiogram were also normal. Peripheral blood smear done $3 \mathrm{~h}$ after the snakebite showed normochromic-normocytic red cells, few fragmented red blood cells $(>4$ in $\times 100$ field), polychromatics, and spherocytes compatible with MAHA. Other laboratory findings are given in Table 2. The patient was self-discharged after $6 \mathrm{~h}$ in the hospital and did not develop any complications after the snakebite. The offending snake species was identified as Hypnale nepa by using the key described by Maduwage et $\mathrm{al}^{1}$ (Figure 8).

\section{Discussion}

We report bites by all 3 species of Hypnale, which caused local envenoming and varying degrees of MAHA as detected in peripheral blood films (fragmented red cells in high power field, $\times 100:>8$ in case $1,>5$ in case 2 , and $>4$ in case 3 ) and other laboratory findings. The first patient developed thrombotic microangiopathy,
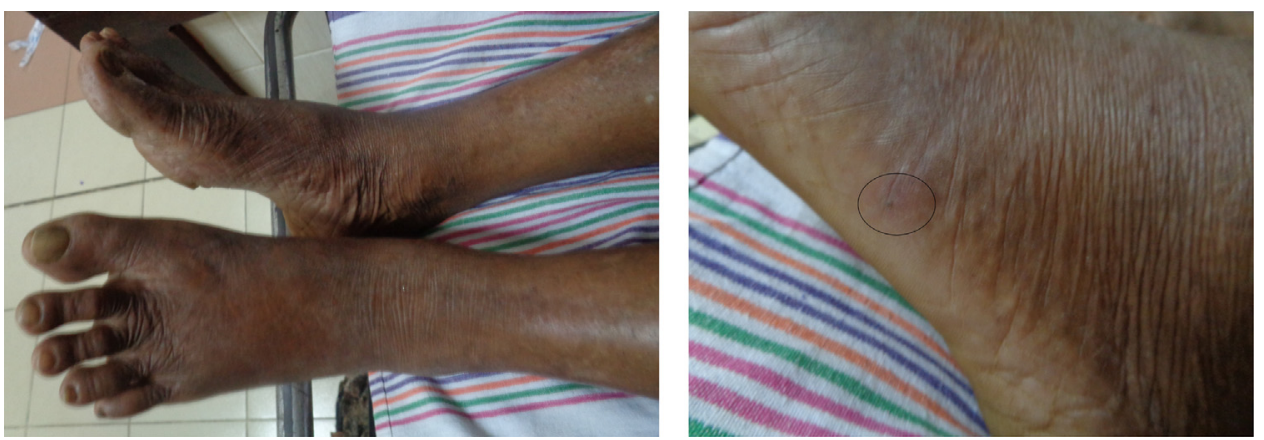

Figure 5. Site of bite in case 2 patient-left foot lateral margin and a fang mark (encircled). 
Table 2. Laboratory findings of case 2 and 3 patients

\begin{tabular}{|c|c|c|c|}
\hline \multirow[t]{2}{*}{ Laboratory investigation } & \multicolumn{2}{|c|}{$\begin{array}{l}\text { Case } 2 \\
\text { patient }\end{array}$} & \multirow{2}{*}{$\begin{array}{l}\begin{array}{l}\text { Case } 3 \\
\text { patient }\end{array} \\
\text { Day } 1 \\
\end{array}$} \\
\hline & Day 1 & Day 2 & \\
\hline WBC $\left(\times 10^{3} \mu \mathrm{L}^{-1}\right)$ & 7.4 & 7 & 5.8 \\
\hline Neutrophils (\%) & 74.2 & 46 & 36 \\
\hline Lymphocytes (\%) & 22.5 & 30.3 & 46.3 \\
\hline Platelets $\left(\times 10^{3} \mathrm{~g} \cdot \mathrm{uL}^{-1}\right)$ & 239 & 302 & 399 \\
\hline $\mathrm{Hb}\left(\mathrm{g} \cdot \mathrm{dL}^{-1}\right)$ & 13 & 12.1 & 10 \\
\hline PCV $(\%)$ & 41.4 & 26.9 & 33 \\
\hline MCV (normal 80-95.5 fL) & 86 & 87 & 80.3 \\
\hline MCH (normal 27-31 Pg) & 27.1 & 28.5 & 24.4 \\
\hline $\begin{array}{l}\mathrm{MCHC} \\
\quad\left(\text { normal } 33-37 \mathrm{~g} \cdot \mathrm{dL}^{-1}\right)\end{array}$ & 31.5 & 32.8 & 30.4 \\
\hline $\begin{array}{l}\text { RBC count } \\
\quad\left(\text { normal } 4-6 \times 10^{6} \mathrm{~g} \cdot \mathrm{uL}^{-1}\right)\end{array}$ & 4.8 & 4.2 & 4.1 \\
\hline MPV (normal 7.8-11 fL) & 7.8 & 8.5 & 8.1 \\
\hline Serum creatinine $\left(\mu \mathrm{mol} \cdot \mathrm{L}^{-1}\right)$ & 87 & 95.5 & 78 \\
\hline $\mathrm{Na}^{+}\left(\mathrm{mmol} \cdot \mathrm{L}^{-1}\right)$ & 146 & 141 & 143 \\
\hline $\mathrm{K}^{+}\left(\mathrm{mmol} \cdot \mathrm{L}^{-1}\right)$ & 4.6 & 3.8 & 3.7 \\
\hline PT (s) & $13 / 12$ & & $11 / 12$ \\
\hline INR & 1.08 & & 0.9 \\
\hline SGOT (AST) $\left[\mathrm{U} \cdot \mathrm{I}^{-1}\right]$ & 28 & & 59 \\
\hline SGPT (ALT) $\left[\mathrm{U} \cdot \mathrm{I}^{-1}\right]$ & 40 & & 28 \\
\hline Total bilirubin $\left(\mu \mathrm{mol} \cdot \mathrm{L}^{-1}\right)$ & 26.3 & & 24.8 \\
\hline
\end{tabular}

WBC, white blood cells; $\mathrm{Hb}$, hemoglobin; PCV, packed cell volume; $\mathrm{MCV}$, mean corpuscular volume; $\mathrm{MCH}$, mean corpuscular hemoglobin; MCHC, mean corpuscular hemoglobin concentration; $\mathrm{RBC}$, red blood cell; MPV, mean platelet volume; $\mathrm{Na}^{+}$, blood sodium level; $\mathrm{K}^{+}$, potassium; PT, prothrombin time; INR, international normalized ratio; SGOT, serum glutamic-oxaloacetic transaminase; AST, aspartate aminotransferase; SGPT, serum glutamic pyruvic transaminase; ALT, alanine aminotransferase.

including the triad of MAHA, thrombocytopenia, and acute kidney injury, which is a known complication of hump-nosed pit viper bite. ${ }^{8}$ However, the patient did not require dialysis, and his renal function returned to normal after several days. He did have a single episode of hyperkalemia, which was corrected with insulin/ dextrose. He had no features of coagulopathy. The second case is the first report of MAHA caused by envenoming from $H$ zara. In Sinhala, this species is called 'Wayiran gelathi kuna katuwa,' meaning 'a hump-nosed pit viper with characteristic color pattern on its neck' (Figure 7C). The patient did not have anemia, and only a marginal drop in hemoglobin was noted. Few reports describing $H$ zara bites have been published. Some of these record only local manifestations of envenoming, including local bleeding, blistering, bruising, lymph node enlargement, and local necrosis, whereas others have documented systemic effects such as coagulopathy and acute kidney injury following $H$ zara bite. ${ }^{6,79}$ The third report is also the first case of MAHA caused by $H$ nepa envenoming. There are 4 documents in literature regarding $H$ nepa bites. $^{6,7,10,11}$

Hypnale venoms cause similar pathological changes with marked differences in the severity of the toxic effects in vivo. The intraperitoneal median lethal doses $\left(\mathrm{LD}_{50}\right)$ for $H$ hypnale, $H$ zara, and $H$ nepa venoms are 1.6, 6.0, and 9.5 microgram protein/g, respectively. ${ }^{12}$ Therefore, the experimental potency of venom effects are $H$ hypnale $>H$ zara $>H$ nepa. In vitro neutralization studies done using Calloselasma rhodostoma (Malayan pit viper) monovalent antivenom and the Hemato polyvalent antivenom (both produced by Thai Red Cross Society, Bangkok, Thailand) showed that the Hemato polyvalent antivenom effectively neutralized the lethality of $H$ hypnale venom $\left(1.52 \mathrm{mg}\right.$ venom $\cdot \mathrm{mL}^{-1}$ antivenom) as well as the hemorrhagic, procoagulant, and necrotic activities of the venom. The monovalent $C$ rhodostoma antivenom could also neutralize the lethality

(B)

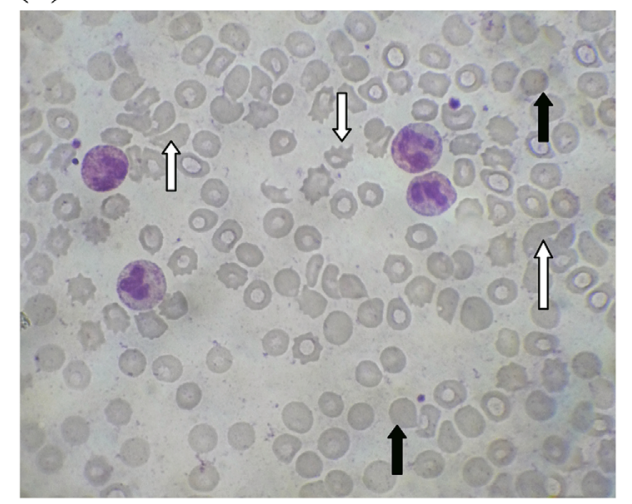

Figure 6. Microangiopathic hemolytic anemia found 7 hours after the snakebite in case 2 patient. White arrow indicates fragmented red blood cells (schistocytes) $>5$ in high power field (B), and black arrow indicates polychromatics. A, $\times 40 ; \mathrm{B}, \times 100$. 
(A)

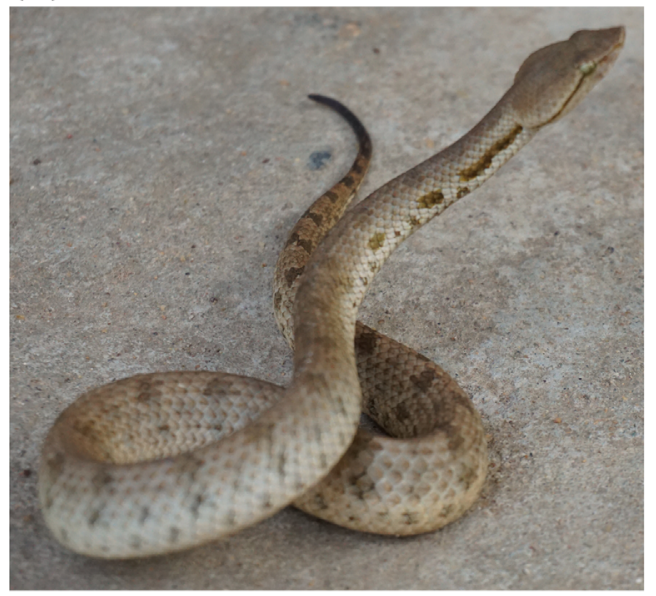

(B)

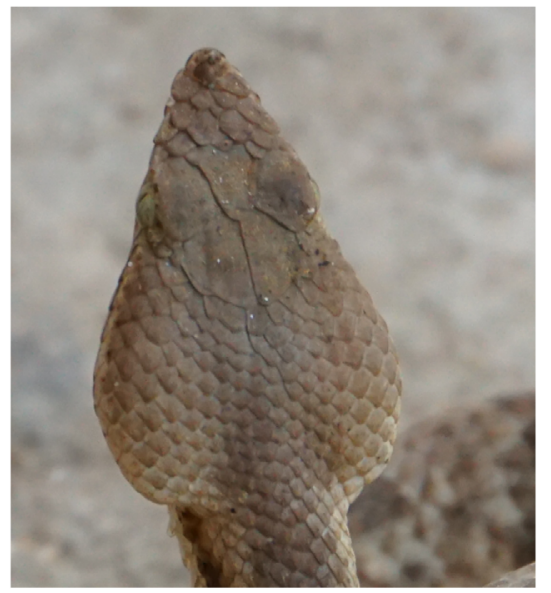

(C)

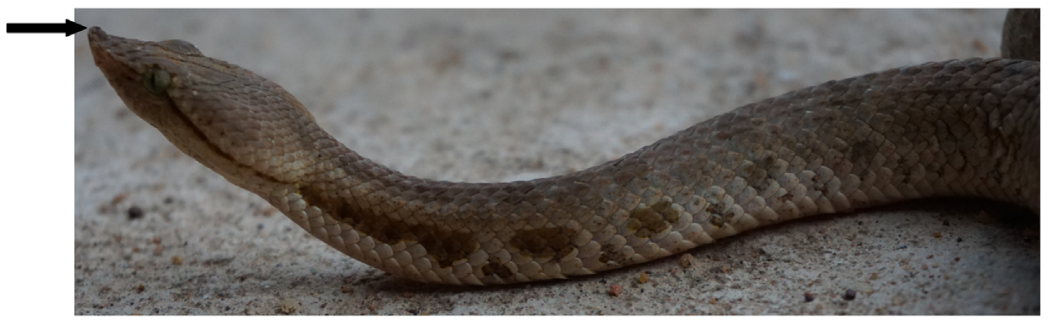

Figure 7. A, Live offending snake (case 2)—H zara, female snake from Kuruvita-Sabaragamuwa province in Sri Lanka, $339 \mathrm{~mm}$ in total length. $\mathrm{B}$, Large head scales, 5 in number. C, Note that the wart-like protuberance at the tip of the snout (hump, indicated by black arrow) is prominent (vs not raised in $H$ hypnale), keeled costal scales, and characteristic color pattern on the neck.

and toxic activities of the venom, but the potency was lower. ${ }^{13}$ In vitro studies have also showed that the 3 Hypnale venoms display similar chromatographic profiles and have potent cytotoxicity, weak neurotoxic and myotoxic activity, and mild procoagulant activity and phospholipase activity. ${ }^{14}$ Prominent hemorrhagic and necrotic effects of $H$ hypnale venom were also assessed in an in vitro rodent model of envenoming. ${ }^{13}$ However, so far, there are no clinical studies that compare these effects of venoms in the genus Hypnale except one, which had a small number of $H$ zara and $H$ nepa bites.

Proteomic investigation of Sri Lankan $H$ hypnale venom revealed that the venom contains a predominance of 2 phospholipase subtypes (E6-PLA 2, W6-PLA ${ }_{2}$; $40.1 \%$ ), followed by snake venom metalloproteases (36.9\%), L-amino acid oxidase (11.9\%), C-type lectins (5.5\%), snake venom serine proteases $(3.3 \%)$, and others (2.3\%). $\mathrm{PLA}_{2}$ causes cell membrane damage, myotoxicity, and myonecrosis, whereas snake venom serine proteases (thrombin-like enzymes) cause venom-induced consumptive coagulopathy. C-type lectins are platelet modulators; they inhibit platelet aggregation, causing hemotoxic effect or potentiate platelet aggregation,
(A)

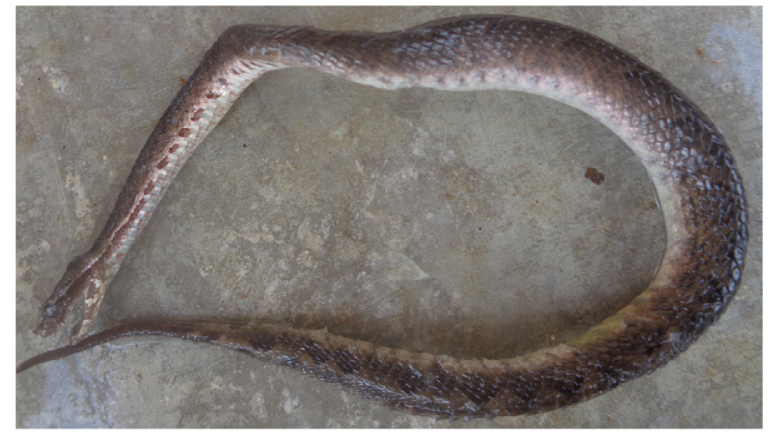

(B)

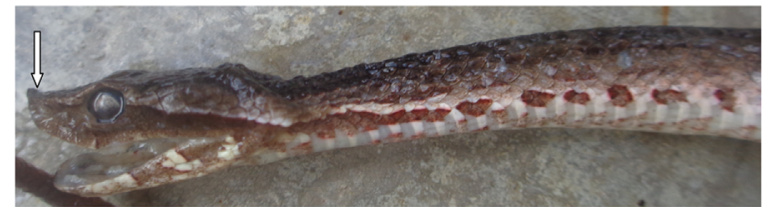

Figure 8. A, Offending snake in case 3 patient $-H$ nepa, a female snake $285 \mathrm{~mm}$ in total length. Note that the costal scales are smooth (not keeled) (vs keeled in $H$ hypnale and $H$ zara). B, Note the flattened or moderately raised snout tip (hump, indicated in white arrow) (vs distinctly raised in $\mathrm{H}$ zara and flattened in $H$ hypnale). 
which leads to thrombocytopenia. L-amino acid oxidase, $\mathrm{PLA}_{2}$, and snake venom metalloproteases that have experimentally reported cytotoxic and tissue damaging properties probably contribute to the effects of local envenomation (acute inflammation, wound hemorrhage, blistering, and necrosis). ${ }^{15}$ However, the nephrotoxic effect of the Hypnale venom remains unclear and may be due to renal hypoperfusion and ischemia caused by venom-induced consumptive coagulopathy. ${ }^{16}$ Most commonly, hump-nosed pit vipers cause local envenoming effects such as pain, swelling, hemorrhagic blistering, and necrosis ${ }^{10,17,18}$ and rarely systemic manifestations like coagulopathy, acute kidney injury, and chronic kidney disease. ${ }^{10,19,20,21}$

MAHA associated with thrombotic microangiopathy is a well-known complication after viperidae snakebites, including hump-nosed pit vipers ${ }^{8,22,23}$ and Russell's vipers (Daboia russelii). ${ }^{24}$ The pathophysiology of MAHA is due to damage of the endothelial layer of small blood vessels with resulting fibrin deposition and platelet aggregation. As red blood cells travel through these damaged vessels, they are fragmented and can be detected in peripheral blood films as schistocytes and helmet cells (Figures 2 and 6). The high amount of $\mathrm{PLA}_{2}$ found in Hypnale venom may damage red blood cell lipid membranes, leading to intravascular hemolysis. MAHA is diagnosed when features of anemia (polychromatics and spherocytes), evidence of hemolysis, and the presence of fragmented red cells ( $>4$ in $\times 100$ field) are observed in peripheral blood smear. Hemolysis is evidenced by elevated indirect bilirubin and lactate dehydrogenase levels and decreased packed cell volume and serum haptoglobin level. We were unable to measure lactate dehydrogenase and haptoglobin levels in these patients due to the resource-poor setting, but hemolysis of patients 1 and 2 was evidenced by the blood picture (fragmented red cells, polychromatics, and spherocytes), reduction of hemoglobin, and packed cell volume with elevated indirect bilirubin level. Because patient 3 selfdischarged, hemolysis was evidenced only from the blood picture and marginal elevation of indirect bilirubin level.

In vitro tests have showed that phospholipase $A_{2}$ in Russell's viper venom causes changes in the morphology of red blood cells, known as sphero-echinocytosis. ${ }^{25}$ It was shown in both in vivo and in vitro tests that the venom of the white-lipped green pit viper (Trimeresurus albolabris) in Thailand has a direct effect on platelets by decreasing mean platelet volume and the number. ${ }^{26,27}$ The venom of this snake also has major effects on red blood cells by decreasing mean corpuscular hemoglobin and mean corpuscular hemoglobin concentration. ${ }^{28}$
In hump-nosed pit viper bites Rathnayaka et al. also observed reduction of mean corpuscular volume in $11.7 \%$, decreased mean corpuscular hemoglobin in $18.4 \%$, reduced mean corpuscular hemoglobin concentration in $9 \%$, and reduction of mean platelet volume in $6.5 \%$ of envenomed patients. ${ }^{29}$ In our patients, however, the red cell indices (MCV, $\mathrm{MCH}, \mathrm{MCHC}$ ) and mean platelet volume reamined normal, and thrombocytopenia was observed only in patient 1 . Even though acute kidney injury associated with MAHA was observed in patient 1, the other 2 patients did not develop any complications after snakebiteassociated MAHA. Microangiopathic hemolysis is observed in $6.8 \%$ of patients following genus Hypnale envenoming. ${ }^{29}$

Although Maduwage et al report that $H$ zara is absent in anthropogenic habitats, ${ }^{1}$ our patient 2 was bitten by $H$ zara in his home garden. These index case series would expand the spectrum of clinical manifestations caused by envenoming from the 3 species of genus Hypnale in Sri Lanka. There should be comparative clinical studies in the future involving envenoming from the 3 species of genus Hypnale.

Acknowledgments: We thank the staff of medical wards, attending medical officers, and consultant physicians in Provincial General Hospital, Ratnapura, Sri Lanka, and the relatives of the patients.

Author Contributions: Literature search (RMMKNR, ANR); humpnosed pit vipers species identification, snake handling, recording of morphological features (RMNKNR); hematological analysis (RJ); drafting of the manuscript (RMMKNR, ANR, SAMK, JR, SR); and approval of the final manuscript (RMMKNR, ANR, SAMK, JR, SR, RJ).

Disclosures: None.

Financial/Material Support: None.

Consent: Written consent for publication of these case histories and photographs was obtained from the patients.

\section{References}

1. Maduwage K, Silva A, Manamendra-Arachchi K, Pethiyagoda RA. A taxonomic revision of the South Asian hump-nosed pit vipers (Squamata: Viperidae: Hypnale). Zootaxia. 2009;2232:1-28.

2. De Silva A, Ranasinghe L. Epidemiology of snake-bite in Sri Lanka: a review. Ceylon Med J. 1983;28(3):144-54.

3. Kasturiratne A, Pathmeswaran A, Fonseka MMD, Lalloo DC, Brooker S, de Silva HJ. Estimates of disease burden due to land-snakebite in Sri Lankan hospitals. Southeast Asian J Trop Med Public Health. 2005;36(3):733-40.

4. De Silva A. Snake bites in Anuradhapura District. The Snake. 1981;13(2):117-30.

5. Kasturiratne A, Wickremasinghe AR, de Silva N, Gunawardena NK, Pathmeswaran A, Premaratna R, et al. The global burden of snakebite: a literature analysis and modeling based on regional estimates of envenoming and deaths. PLoS Med. 2008;5(11):e218. 
6. Maduwage K, Isbister GK, Silva A, Bowatta S, Mendis S, Gawarammana I. Epidemiology and clinical effects of hump-nosed pit viper (Genus: Hypnale) envenoming in Sri Lanka. Toxicon. 2013;61:11-5.

7. Namal Rathnayaka RMMK, Kularatne SAM, Ranathunga PEAN, Rajapakse RPVJ, Ranasinghe JGS. Species specific clinical manifestations following Hump-nosed pit viper (Genus: Hypnale) envenoming in Sri Lanka. In: Sri Lanka Medical Association 130th Anniversary International Medical Congress. July 13-16, 2017; Colombo, Sri Lanka. Ceylon Med J. (Suppl 1). 2017;62:97.

8. Herath N, Wazil A, Kularatne S, Ratnatunga N, Weerakoon K, Badurdeen S, et al. Thrombotic microangiopathy and acute kidney injury in hump-nosed viper (Hypnale species) envenoming: a descriptive study in Sri Lanka. Toxicon. 2012;60(1):61-5.

9. Maduwage K, Kularatne K, Wazil A, Gawarammana I. Coagulopathy, acute kidney injury and death following Hypnale zara envenoming-the first case report from Sri Lanka. Toxicon. 2011;58(8):641-3.

10. Ariaratnam CA, Thuraisingam V, Kularatne SA, Sheriff MH, Theakston RD, de Silva A, et al. Frequent and potentially fatal envenoming by hump-nosed pit vipers (Hypnale hypnale and $H$ nepa) in Sri Lanka: lack of effective antivenom. Trans $R$ Soc Trop Med Hyg. 2008; 102(11):1120-6.

11. De Silva A. Hypnale nepa bite: first record. Proceedings of the Kandy Soc Med. 1989;11:8-10.

12. Silva A, Gunawardena P, Weilgama D, Maduwage K, Gawarammana I. Comparative in-vivo toxicity of venoms from South Asian hump-nosed pit vipers (Viperidae: Crotalinae: Hypnale). BMC Res Notes. 2012;5:471.

13. Tan CH, Leong PK, Fung SY, Sim SM, Ponnudurai G, Ariaratnam $\mathrm{C}$, et al. Cross neutralization of Hypnale hypnale (hump-nosed pit viper) venom by polyvalent and monovalent Malayan pit viper antivenoms in vitro and in a rodent model. Acta Trop. 2011;117(2):119-24.

14. Maduwagea K, Hodgson WC, Konstantakopoulos N, O'Leary MA, Gawarammana I, Isbister GK. The in vitro toxicity of venoms from South Asian Hump-nosed pit vipers (Viperidae: Hypnale). J Venom Res. 2011;2:17-23.

15. Tan CH, Tan NH, Sim SM, Fung SY, Gnanathasan CA. Proteomic investigation of Sri Lankan hump-nosed pit viper (Hypnale hypnale) venom. Toxicon. 2015;93:164-70.

16. Sitprija V. Animal toxins and the kidney. Nat clin Pract Nephrol. 2008;4(11):616-27.

17. Sellahewa KH, Kumararatne MP. Envenomation by the hump-nosed Viper (Hypnale hypnale). Am J Trop Med Hyg. 1994;51(6):823-5.
18. Wijewantha HS, Sellahewa KH. Hump nosed viper bite in Sri Lanka-descriptive observational study of 1543 cases. Asian Pac J Trop Med. 2010;3(11):902-5.

19. Namal Rathnayaka RMMK, Kularatne SAM, Ranathunga PEAN, Kumarasinghe KDM, Rajapakshe RPVJ, Ranasinghe JGS. Prolonged coagulopathy, ecchymoses and microangipathic haemolytic anaemia following hump-nosed pit viper (Hypnale hypnale) bite in Sri Lanka. Wilderness Environ Med. 2017;28(3):253-8.

20. Kularatne SAM, Ratnatunga N. Severe systemic effects of Merrem's hump-nosed viper bite. Ceylon Med J. 1999; 144(4):169-70.

21. Namal Rathnayaka RMMK, Ranathunga PEAN. Acute kidney injury which leads to chronic kidney disease and death following hump nosed pit viper (Genus: Hypnale) envenoming. J Ratnapura Clin Soc. 2016;11:40-2.

22. Joseph JK, Simpson ID, Menon NCS, Jose MP, Kulkarni KJ, Raghavendra GB, et al. First authenticated cases of life-threatening envenoming by the hump-nosed pit viper (Hypnale hypnale) in India. Trans $R$ Soc Trop Med Hyg. 2007;101(1):85-90.

23. Karunatilake H, Nayakarathna T, Atapattu S, Saparamadu T, Dharmasena S. Thrombotic microangiopathy and fibrinolysis after hump-nosed viper envenomation. Ceylon Med J. 2012;57(1):45-6.

24. Kularatne SAM, Wimalasooriya S, Nazar K, Maduwage K. Thrombotic microangiopathy following Russell's viper (Daboia russelii) envenoming in Sri Lanka: a case report. Ceylon Medical J. 2014;59(1):29-30.

25. Napathorn S, Tejachokviwat M, Maneesri S, Kasantikul V, Sitprija V. Effects of Russell's viper venom on human erythrocytes in vitro. J Natural Toxins. 1998;7(1):73-85.

26. Soogarun S, Wiwanitkit V, Suwansaksri J. A trend of platelet indices in patients with green pit viper toxin. Clin Appl Thromb Hemost. 2003;9(4):337-9.

27. Soogarun S, Choewbamrungkiat M, Wiwanitkit V. Study on the effect of green pit viper venom (Trimeresurus albolabris) on platelet morphology by flow cytometry. Online J Health \& Allied Sci. 2006;5(3).

28. Wiwanitkit V, Suswansaksri S. Effect of green pit viper toxin on red blood cell index (an interim analysis). Toxicology. 2001;164(Suppl.1):178.

29. Namal Rathnayaka RMMK, Nishanthi Ranathunga PEA, Kularatne SAM, Radha Jayathunga, Kumarasinghe KDM, Jeganadan K. Epidemiology and haematological manifestations following Hump -nosed pit viper (Genus: Hypnale) envenoming in the region of Ratnapura (Sabaragamuwa Province - wet zone of Sri Lanka). J Ratnapura Clin Soc. 2017;11:30-8. 